\title{
FLORA DE GRÃO-MOGOL, MINAS GERAIS: PENTAPHYLACACEAE (TERNSTROEMIACEAE) ${ }^{1}$
}

\author{
MARTA CAMARGO ASSIS \\ Departamento de Botânica, Instituto de Biociências, Universidade de São Paulo, \\ Caixa Postal 11461, 05422-970 - São Paulo, SP, Brasil. \\ endereço atual: Centro Nacional de Pesquisa em Monitoramento por Satélite, CNPM/EMBRAPA, \\ Av. Dr. Júlio Soares de Arruda, 803, 13088-300 - Campinas, SP, Brasil.
}

Bittrich, V. \& Weitzman, A.L. 2002. Theaceae. In M.G.L. Wanderley, G.J. Shepherd, A.M. Giulietti, T.S.A. Melhem, V. Bittrich \& C. Kameyama (eds.) Flora fanerogâmica do Estado de São Paulo. FAPESP, HUCITEC. São Paulo, vol. 2, p. 323-326. Kobuski, C.E. 1942. Studies in the Theaceae, XII. Notes on the South American species of Ternstroemia. J. Arnold Arbor. 23 : 298-343.

Temponi, L.G., Udulutsch, R.G. \& Koehler, S. 2004. Flora da Serra do Cipó, Minas Gerais: Pentaphylacaceae (Ternstroemiaceae). Bol. Bot. Univ. São Paulo 22(1): 35-38.

Wawra von Fernsee, H. 1886. Ternstroemiaceae. In C.F.P. Martius \& A.G. Eichler (eds.) Flora brasiliensis. Frid. Fleischer. Leipzig, vol. 12, pars 1, p. 261-334, tab. 52-68.

\section{Ternstroemia Mutis ex L.f.}

Árvores ou arbustos, ramos subopostos ou verticilados. Folhas espiraladas, congestas ou verticiladas no ápice, coriáceas, inteiras ou quase. Flores axilares, solitárias, bracteolada, monóicas; sépalas 5, pétalas 5, estames 25-300, geralmente bisseriados, filetes conatos; ovário 2-3-locular, 2-multiovulado, óvulos pêndulos. Fruto geralmente indeiscente.

1. Estigma peltado; estames 25 .

T. carnosa

1 '. Estigma punctado; estames 45 T. brasiliensis

\subsection{Ternstroemia brasiliensis Cambess. in A.St.-Hil.,} F1. Bras. merid. 1: 298; tab. 59. 1827.

Arvoreta ca. $3 \mathrm{~m}$ alt., ramos glabros. Folhas oblongoobovadas a elípticas, coriáceas, 2,5-5,5 cm compr., 1,5-2,5 $\mathrm{cm}$ larg., ápice retuso, base atenuada, margem ligeiramente serrulada, revoluta, com pontuações enegrecidas. Flores geralmente solitárias; pedicelo ca. $1,5 \mathrm{~cm}$ compr.; brácteas 2, denteadas, opostas. Sépalas 5, lobadas, lobos externos 2, denteados, os internos 3, inteiros; ovário 3-locular, 2 óvulos por lóculo.

Oliveira et al. CFCR 13080 (SPF).

Rio de Janeiro e Minas Gerais. Em Grão-Mogol, ocorre entre rochas, em solo arenoso, ca. 1000 m s.m. Foi coletada com flores em junho.
1.2. Ternstroemia carnosa Cambess. in A.St.-Hil., Fl. Bras. merid. 1: 299. 1827.

Arbusto ca. $3 \mathrm{~m}$ alt. Folhas obovais a elípticas, coriáceas, 2,8-4 cm compr., 1,5-2,3 cm larg., ápice arredondado, base atenuada, margem levemente serrilhada, revoluta. Lobos do cálice externamente com glândulas denticuladas; estames bisseriados, filetes curtos; estigma 2-3-lobado; ovário 2-locular com 2 óvulos por lóculo. Frutos imaturos verdes, maduros amarelados a avermelhados. (Fig. 1. A-D)

Hensold et al. CFCR 3447 (SPF); Mello-Silva \& Cordeiro CFCR 10087, CFCR 10089 (SPF); Simão-Bianchini et al. 13079 (SPF).

Ocorre na Bahia, Goiás, Minas Gerais e São Paulo, geralmente em ambientes rochosos. Em Grão-Mogol, foi coletada entre rochas, em campo rupestre, a ca. 920 m s.m. Frutifica em maio e setembro, quando também foram encontrados botões e poucas flores abertas.

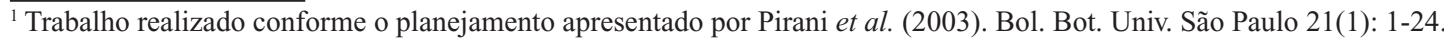



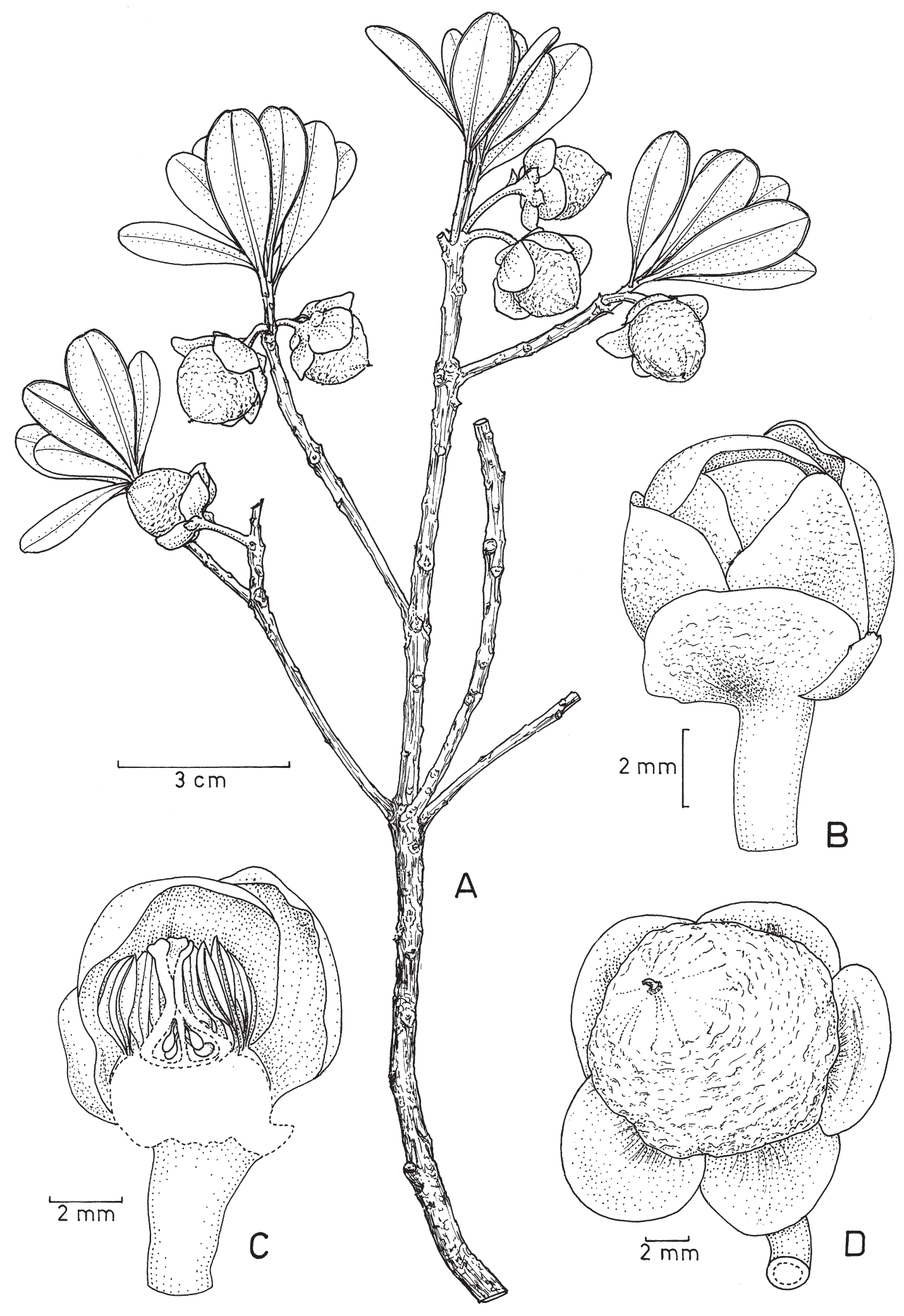

Fig. 1. PENTAPHYLACACEAE. Ternstroemia carnosa. A. Hábito com frutos; B. Botão; C. Botão, corte longitudinal mostrando os estames adnatos, estigma peltado e ovário bilocular, biovulado; D. Fruto. 